Available online on 15.07.2021 at http://ujpr.org
Universal Journal of Pharmaceutical Research
An International Peer Reviewed Journal
Open access to Pharmaceutical research is an open access article distributed under the terms of the Creative Commons Attribution-Non
Commercial Share Alike 4.0 License which permits unrestricted non commercial use,
provided the original work is properly cited
Volume 6, Issue 3, 2021

\title{
VULVOVAGINAL CANDIDIASIS: PREVALENCE, SPECIES DISTRIBUTION AND RISK FACTORS AMONG NON-PREGNANT WOMEN, IN SANA'A, YEMEN
}

Sameera Mohammad Mahdi Al-Hatami ${ }^{1}{ }^{1}$, Khaled Abdulkareem A Al-Moyed ${ }^{1}(\mathbb{D}$, Hassan Abdulwahab Al-Shamahy ${ }^{1}{ }^{\oplus}$, Ahmed Mohammed Al-Haddad ${ }^{2}{ }^{\circ}$, Azhar Azher Mohammed Al-Ankoshy ${ }^{3}$ (D)

${ }^{I}$ Department of Medical Microbiology and Clinical Immunology, Faculty of Medicine and Health Sciences, Sana'a University, Republic of Yemen.

${ }^{2}$ Department of Medical Laboratories, College of Medicine and Health Sciences, Hadhramout University, Al-Mukalla, Yemen. ${ }^{3}$ Jabir ibn Hayyan Medical University, Faculty of Medicine, Iraq.

\section{ABSTRACT}

Background and objectives: Vulvovaginal candidiasis is known to be a global issue of concern due to its association with economic costs, sexually transmitted diseases, and the escalation of genital tract infections. This study aimed to determine the prevalence, species distribution and risk factors associated with Candida species causing vulvovaginal candidiasis.

Subjects and Methods: Non-pregnant women attending routine antenatal visits at Al-Olaifi-Family Center in Sana'a were enrolled in a cross-sectional study conducted from June 2018 to March 2019. Laboratory work was carried out at the National Center of Public Laboratories (NCPHL). Vaginal swabs were sampled from participants after oral consent was obtained. The swabs were inoculated in Sabouraud glucose agar supplemented with chloramphenicol and incubated at $37^{\circ} \mathrm{C}$ for 24 to $48 \mathrm{~h}$ under aerobic conditions in order to perform a fungal culture. Candida species were determined by culturing on HiCrome Candida differential Agar at $35^{\circ} \mathrm{C}$ for $48 \mathrm{~h}$ to produce species-specific colours. Data on demographic, clinical, and risk factors were collected in a pre-designed questionnaire.

Results: A total of 190 non-pregnant women were included. The prevalence of VVC was $22.1 \%$. Candida albicans accounted for $16.3 \%$ and non-Candida albicans accounted for $5.8 \%$ of the isolates, mainly C. glabrata (3.2\%), C. rugosa (1.05\%), C. lipolytica $(1.05 \%)$, and C. dubliniensis $(0.53 \%)$. When VVC risk factors were considered, there were significant risk factors with age group $30-34$ years $(33.3 \%$, odds ratio $=2.1)$ and age group $\geq 35$ years $(62.5 \%$, odds ratio $=10.3)$, residence in a rural area $(39.5 \%, O R=3.3)$, negative emotions $(30.2 \%$, OR=2.3), underwear replacement over 1 day $(29.3 \%$, OR=4.2), impure cotton underwear $(29.4 \%$, $\mathrm{OR}=4.9$ ), while Condom use and vulvar cleaning before or after sexual life were found to be highly significant protective factors against VVC ( $p=0.008,0.03$, respectively).

Conclusions: Guidelines for the management of VVC syndrome in Yemen should be revised to include a protocol specifically for women over 30 years of age. VVC undoubtedly poses a significant threat to women's reproductive health. Risk factors for VVC are varied, and include ages, health habits, history of the disease, and other aspects. It is necessary to take appropriate measures to avoid risk factors and to help reduce the prevalence of VVC among women of childbearing age.

Keywords: Candida, Vulvovaginal candidiasis, VVC, Epidemiology, Risk factors, Sana'a, Yemen.

Article Info: Received 18 April 2021; Revised 29 May; Accepted 4 July, Available online 15 July 2021

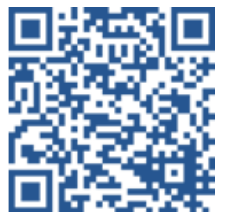

\section{Cite this article-}

Al-Hatami SMM, Al-Moyed KAA, Al-Shamahy HA, Al-Haddad AM, Al-Ankoshy AAM. Vulvovaginal candidiasis: prevalence, species distribution and risk factors among non-pregnant women, in Sana'a, Yemen. Universal Journal of Pharmaceutical Research 2021; 6(3):30-36.

DOI: https://doi.org/10.22270/ujpr.v6i3.613

Address for Correspondence

Prof. Hassan A. Al-Shamahy, Faculty of Dentistry, Sana'a University, P.O. Box 775 Sana'a, Yemen, Tel- +967-770299847; E-mail: shmahe@yemen.net.ye

\section{INTRODUCTION}

Candidiasis is a fungal infection caused by any species of Candida. It affects the mouth and vagina, while the penis is less common and very rare, Candida infection may become invasive, spreading to other parts of the body ${ }^{1-7}$. Vulvovaginal candidiasis (VVC) is the second most widespread type of vaginal infection among women of childbearing age, involve mainly the vulva and vagina. It is expected that about $70-75 \%$ of women 
of childbearing age will experience at least one episode of VVC during their lifetime and that $40-50 \%$ will experience recurrence ${ }^{8}$. Approximately $80-90 \%$ of VVC is produced by Candida albicans excluding that only a minor of cases (10-20\%) are caused as a result of non-C. albicans, commonly Candida glabrata ${ }^{9}$. Part of the normal vaginal microflora is Candida albicans. It is known to have become a powerful opportunistic fungal pathogen and is the main causative agent of VVC in case the body lacks protective immunity and has a rebellion of purification insurgence to clearance 10. Furthermore, the anus is anatomically adjacent to the vagina, which tenders much appropriateness for the migration of intestinal organisms, including Candida, into the vagina. VVC causes untold inconvenience to many patients, poses a serious problem for clinicians, and produces significant direct and indirect economic costs associated with medications and healthcare visits. Infection of the vagina or vulva may be associated with symptoms and signs such as pain, severe itching, pruritus inflammation, irritation, foul odor, dysuria and burning during urination ${ }^{8}$. It has been found in the Arab countries that the epidemic of VVC infection varies in different countries ${ }^{11-13}$. Thus, local studies are important to obtain relevant epidemiological data and sensitivity characteristics of Candida to antifungal drugs in order to aid the management and treatment of patients with Candida infection. Vaginitis in Yemen is one of the most common conditions to seek medical care. In Sana'a city, vaginal infections were prevalent in Yemen among 37.6\% of women of reproductive age, $50 \%$ among pregnant women and where VVC was significantly associated with younger age female and intrauterine contraceptive use $e^{4,5,14}$. Also in Hadhramaut $372(39.2 \%)$ of 950 pregnant women had abnormal vaginal discharge and were positive for bacterial vaginosis ${ }^{15}$. Currently, the high rate of VVC infection was $70.45 \%$ recorded among pregnant women in Hajjah governorate ${ }^{16}$. According to the current epidemiological studies, the prevalence and incidence of genital tract infections differ between countries and ethnicities $^{4,5,17,18}$. Even in similar populations, the epidemiological features of low reproductive tract infection differ ${ }^{19}$. It is therefore important to analyze the risk factors for VVC among women of reproductive age in Sana'a city and then provide a reference for clinical prevention and treatment of VVC.

\section{SUBJECTS AND METHODS}

Non-pregnant women attending routine antenatal visits in Al-Olify -family Center in Sana'a city were enrolled in a cross-sectional study was conducted from June 2018 to March 2019 which is the time given by the NCPHL to complete the study. Inclusion criteria for subject selection were healthy individuals with no systemic disease. In addition, non-pregnant women who currently taking antifungal, steroids, antibiotics, or immunosuppressive drugs in the past 6 months were excluded. The sample included 190 non-pregnant mothers who met the inclusion criteria and agreed to participate in the study. All non-pregnant females at reproductive age was examined clinically by a specialist and vaginal swabs were taken. The vaginal swabs were sent to the National Center of Public Laboratories (NCPHL) where the laboratory works were carried out. Vaginal swabs samples were taken from participants after obtaining oral consent. The swabs were inoculated into Sabouraud's glucose agar supplemented with chloramphenicol and incubated at $37^{\circ} \mathrm{C}$ for 24 to 48 hours under aerobic conditions in order to perform a fungal culture. The identification of the Candida species was done by culture on HiCrome Candida Differential Agar at $35^{\circ} \mathrm{C}$ for $48 \mathrm{~h}$ for the production of species-specific colors. Data of demographic, clinical and risk factors were collected in a pre-designed questionnaire.

\section{Statistical analysis}

The data was statistically analyzed using EPI-Info version 6. The difference in the distribution of Candida types among groups was based on a comparison of repeat distributions by chi-square test. The odds ratio associated with VVC risk factors was performed by $2 \times 2$ tables to obtain an OR, 95\% CI, Chi squared and $\mathrm{p}$ value by uncorrected static tests where the value of $p<0.05$ was considered significant.

\section{Ethical approval}

The written consent in all cases were obtained. Approval was obtained from the participants prior to collection of samples. Ethical approval was obtained from the Medical Research and Ethics Committee of the Faculty of Medicine and Health Sciences, Sana'a University with reference number (95) on 11/05/2018.

Table 1: The distribution of non pregnant women according to their age group.

\begin{tabular}{ccc}
\hline Age groups & \multicolumn{2}{c}{$\begin{array}{c}\text { Non pregnant women } \\
\text { n=190 }\end{array}$} \\
\cline { 2 - 3 } & No. & \% \\
\hline <20 years & 12 & 6.3 \\
20-24 years & 58 & 30.5 \\
25-29 years & 46 & 24.2 \\
30-34 years & 42 & 22.1 \\
$\geq 35$ & 32 & 16.8 \\
Mean age & \multicolumn{2}{c}{27.1 years } \\
S. D & \multicolumn{2}{c}{5.7 years } \\
Mode & \multicolumn{2}{c}{ 30 years } \\
Median & \multicolumn{2}{c}{ 26 years } \\
Max & \multicolumn{2}{c}{ 40 years } \\
Min & \multicolumn{2}{c}{ 16 years } \\
Total & \multicolumn{2}{c}{ 190 } \\
\hline \multicolumn{2}{c}{}
\end{tabular}


Table 2: The frequency of different species of Candida isolated from non-pregnant women.

\begin{tabular}{lcc}
\hline \multirow{2}{*}{$\begin{array}{l}\text { Micro-organism } \\
\text { species }\end{array}$} & \multicolumn{2}{c}{$\begin{array}{c}\text { Non-Pregnant } \\
\text { women }\end{array}$} \\
\cline { 2 - 3 } & No. & $\%$ \\
\hline Candida spp & 42 & 22.1 \\
Candida albicans & 31 & 16.3 \\
Non-candida & 11 & 5.8 \\
albicans spp & & 3.2 \\
C. globrata & 6 & 0.53 \\
C. dubliniensis & 1 & 1.05 \\
C. rugosa & 2 & 1.05 \\
C. lipolytica & 2 & \\
\hline
\end{tabular}

\section{RESULTS}

A total of 190 non-pregnant women were included. The prevalence of VVC was $22.1 \%$. Candida albicans accounted for $16.3 \%$ and non-Candida albicans accounted for $5.8 \%$ of the isolates, mainly $C$. glabrata $(3.2 \%)$, C. rugosa $(1.05 \%)$, C. lipolytica $(1.05 \%)$, and C. dubliniensis $(0.53 \%)$. When VVC risk factors were considered, there were significant risk factors with age group 30-34 years $(33.3 \%$, odds ratio $=2.1)$ and age group, 35 years $(62.5 \%$, odds ratio $=10.3)$, residence in a rural area $(39.5 \%), \mathrm{OR}=3.3)$, negative emotions $(30.2 \%, \mathrm{OR}=2.3)$, underwear replacement over 1 day (29.3\%, OR=4.2), impure cotton underwear $(29.4 \%$, $\mathrm{OR}=4.9$ ), while Condom use and vulvar cleaning before or after sexual life were found to be highly significant protective factors against VVC $(p=0.008$, 0.03 , respectively). Detailed results of the study are presented in Table 1 to Table 5.

Table 3: The prevalence rate and risk of developing candidiasis among different age groups of non-pregnant women.

\begin{tabular}{lcccccc}
\hline \multirow{2}{*}{$\begin{array}{l}\text { Age group } \\
\text { in years }\end{array}$} & \multicolumn{9}{c}{ Positive $\mathbf{n = 4 2}$} & OR & CI & $\mathbf{X}^{\mathbf{2}}$ & PV \\
\cline { 2 - 5 } & $\mathbf{N o}$ & $\mathbf{\%}$ & & & & \\
\hline$<20$ years $(\mathrm{n}=12)$ & 0.0 & 0.0 & 0 & undefined & 3.6 & 0.056 \\
20-24years $(\mathrm{n}=58)$ & 4 & 8.6 & 0.18 & $0.06-0.5$ & 11.2 & 0.0008 \\
25-29 years $(\mathrm{n}=46)$ & 14 & 30.4 & 1.8 & $0.8-3.8$ & 2.4 & 0.11 \\
30-34 years $(\mathrm{n}=42)$ & 14 & 33.3 & 2.1 & $1.0-4.5$ & 3.9 & 0.04 \\
$>$ 35 years $(\mathrm{n}=32)$ & 20 & 62.5 & 10.3 & $4.4-24$ & 36.4 & 0.000 \\
Total $(\mathrm{n}=190)$ & 42 & 22.1 & & & & \\
\hline
\end{tabular}

\section{DISCUSSION}

VVC is a health problem that affects millions of women and is caused by the overgrowth of yeasts in the vaginal mucosa ${ }^{20}$. It causes many vaginal signs and symptoms, including cottage cheese-like discharge associated with vaginal and vulvar itching, pain, burning sensation, erythema, and edema. External dysuria and dyspareunia may also occur ${ }^{21}$. The rate of infection in the present study $(22.1 \%)$ was somewhat similar to the reported range $\mathrm{e}^{22}$ and was higher than the rates described by Ahmed et al., in India among pregnant and non-pregnant women ${ }^{23}$ and Olowe et al., in Nigeria among pregnant women ${ }^{24}$, but a lower rate was described by ERylander et al., among sexually active young women and correlation with oral-genital $\operatorname{sex}^{25}$.

The dissimilarities in rates can be justified by identifying variations in sociodemographic characteristics and immune status of patients ${ }^{26}$, and treatment of patients with broad antibiotics, immunosuppressive drugs ${ }^{27}$ and hormonal effects ${ }^{28}$ as some of the factors for the differences in prevalence and/or recurrent vulvovaginal candidiasis between studies. The prevalence of VVC was $22.1 \%$. Candida albicans accounted for $16.3 \%$ and non-Candida albicans accounted for $5.8 \%$ of the isolates, mainly C. glabrata (3.2\%), C. rugosa (1.05\%), C. lipolytica $(1.05 \%)$, and C. dubliniensis $(0.53 \%)$ (Table 2).
This result with respect to VVC-causing species, is similar to that reported by other researchers where Candida albicans is the prodrome and increased prevalence of non-Candida albicans species, especially C. glabrata, C. krusei and C. parapsilosis ${ }^{29}$. Some researchers have also found that the incidence of infection with Candida albicans is reduced and that of other Candida species including $C$. glabrata. $C$. tropical, C. parapsilosis, C. kefyr, C. africana, $C$. dubliniensis, C. Famata, C. Guilliermondii and $C$. lusitaniae mainly associated with vulvovaginitis of immunocompromised patients or in pregnant women ${ }^{30}$. This study showed that women in the age group 30-34 years and $>35$ years have a double and 10-fold risk of developing VVC, respectively, compared to younger age groups (Table 2, and Table 3). However, age at first sexual intercourse $<20$ years increased the risk of VVC by two times $(\mathrm{OR}=2)$. The current study differs from that reported by Zeng et al., in which younger women were at double the risk of developing VVC compared to the elderly ${ }^{21}$. The results of the current study are also in line with the facts described that chance was the cause of increased Candida vaginitis in women of childbearing age and not in menopause $\mathrm{e}^{30}$. The reason why VVC is more common in the third and fourth decade of life may lie in the fact that they are easy to suffer from negative factors such as risky sexual behaviors ${ }^{31}$ 
Table 4: Univariate analysis of socioeconomic factors and daily living habits among non-pregnant women of reproductive age.

\begin{tabular}{|c|c|c|c|c|c|c|}
\hline \multirow[t]{2}{*}{ Character } & \multicolumn{2}{|c|}{$\begin{array}{l}\text { Candida species } \\
\text { positive }(n=42)\end{array}$} & \multirow[t]{2}{*}{ OR } & \multirow[t]{2}{*}{ CI } & \multirow[t]{2}{*}{$\mathbf{X}^{2}$} & \multirow[t]{2}{*}{$\mathbf{P V}$} \\
\hline & No. & $\%$ & & & & \\
\hline \multicolumn{7}{|l|}{ Residence } \\
\hline Rural area $(n=43)$ & 17 & 39.5 & 3.3 & $1.5-7$ & 10.5 & 0.0001 \\
\hline Urban $(n=147)$ & 25 & 17 & 0.29 & $0.14-0.7$ & 10.5 & 0.0001 \\
\hline \multicolumn{7}{|c|}{ Educational background } \\
\hline $\begin{array}{l}\text { Secondary or below } \\
(\mathrm{n}=152)\end{array}$ & 36 & 23.7 & 1.6 & $0.6-4.2$ & 1.1 & 0.29 \\
\hline $\begin{array}{l}\text { College or above } \\
(\mathrm{n}=38\end{array}$ & 6 & 15.8 & 0.6 & $0.2-1.5$ & 1.1 & 0.29 \\
\hline \multicolumn{7}{|l|}{ Daily emotional state } \\
\hline $\begin{array}{l}\text { Negative emotions } \\
\text { (nervousness, anxiety, } \\
\text { etc.) }(n=86)\end{array}$ & 26 & 30.2 & 2.3 & $1.1-4.8$ & 6 & 0.001 \\
\hline Comfort $(n=104)$ & 16 & 15.4 & 0.47 & $0.2-0.8$ & 6 & 0.001 \\
\hline \multicolumn{7}{|c|}{ Usage of pad during non-menstruation } \\
\hline No $(n=121)$ & 23 & 27.3 & 0.6 & $0.3-1.2$ & 1.8 & 0.17 \\
\hline Yes $(n=69)$ & 19 & 27.5 & 1.6 & $0.8-3.2$ & 1.8 & 0.17 \\
\hline \multicolumn{7}{|c|}{ Wiping direction after the toilet } \\
\hline $\begin{array}{l}\text { Forward wiping } \\
(\mathrm{n}=83)\end{array}$ & 17 & 20.5 & 0.8 & $0.4-1.6$ & 0.22 & 0.6 \\
\hline $\begin{array}{l}\text { Backward wiping } \\
(\mathrm{n}=107)\end{array}$ & 25 & 23.4 & 1.1 & $0.6-2.3$ & 0.22 & 0.6 \\
\hline \multicolumn{7}{|c|}{ Frequency of underwear replacement } \\
\hline Over one day $(n=123)$ & 36 & 29.3 & 4.2 & $1.6-10.6$ & 10.3 & 0.0001 \\
\hline $\begin{array}{l}\text { Less than one day } \\
\mathrm{n}=67)\end{array}$ & 6 & 8.9 & 0.2 & $\begin{array}{c}0.09- \\
0.59 \\
\end{array}$ & 10.3 & 0.0001 \\
\hline \multicolumn{7}{|c|}{ Frequency of wearing tights } \\
\hline $\begin{array}{l}\text { Occasionally or never } \\
(\mathrm{n}=111)\end{array}$ & 24 & 21.6 & 0.9 & $0.4-1.8$ & 0.36 & 0.84 \\
\hline Frequently $(\mathrm{n}=79)$ & 18 & 22.8 & 1.1 & $0.5-2.1$ & 0.36 & 0.84 \\
\hline \multicolumn{7}{|l|}{ Underwear material } \\
\hline Others $(\mathrm{n}=126)$ & 37 & 29.4 & 4.9 & $1.8-13$ & 11.4 & 0.0002 \\
\hline Pure cotton $(n=64)$ & 5 & 7.8 & 0.2 & $0.07-0.5$ & 11.4 & 0.0002 \\
\hline
\end{tabular}

In addition to some physiological and histological changes caused by reproductive hormones that occur in women during this stage of life (third and fourth decade), which increase the susceptibility to Candida infection. In this study, area of rural residence showed a significant effect on the incidence of VVC $(\mathrm{OR}=3.3$, $\mathrm{CI}=1.5-7, p=0.0001$ ) (Table 4). However, a previous study indicated that episodes of VVC symptoms were not significantly associated with residency ${ }^{21,32}$. The difference can be explained by the fact that there was difference between rural and urban areas with greater awareness of self-care and better medical conditions in current times. At the same time, people from different educational backgrounds cannot get the same avenues to get the vast information related to healthcare through the internet ${ }^{21,33,34}$. In the current study, educational background showed no effect on the incidence of VVC $(p=0.29) \quad$ (Table 4). However, a previous study indicated that higher education can protect against infection $^{33}$. In the current study, use of pads during non-menstruation, trend of wiping after toilet, and frequency of wearing tights clothes did not show any effect on the incidence of VVC. However, previous studies indicated that episodes of VVC symptoms were significantly associated with these factors ${ }^{21,32}$. The overall crude prevalence of diabetes among women of reproductive age in Yemen is $6.3 \%^{35}$ and this rate is consistent with this study where 14 females had DM2 (6\%), resulting in a VVC $(\mathrm{OR}=3.7, \mathrm{CI}=1.1-13.2, p=$ 0.02 ) (Table 5). This finding is similar to studies ${ }^{34,36,37}$ that showed that diabetes mellitus, especially uncontrolled diabetes mellitus, led to VVC. This study explored that frequent vaginal douching can increase susceptibility to VVC with risk factors equal to 7 times $(p<0.0001)$ (Table 5). This is in line with the results of previous studies ${ }^{21,32,33}$. The reason may lie in the fact that intravaginal practices can cause damage to the tissues of the vagina and rectum and also disrupt the vaginal flora. Furthermore, the use of a vaginal douche may upset the balance of the delicate ecosystem of the vagina, lead to a regression of the vaginal balance, encourage the growth of yeasts, and also cause VVC. By contrast, one study confirmed that the association between intravaginal practices and VVC was not specific $^{38}$.

This study identified one-day underwear substitution as a risk factor for VVC $(\mathrm{OR}=4.2, \mathrm{CI}=1.6-10.6, p=0.000$ 1) (Table 4), as there was an association between under-wear material and VVC where impure cotton underwear clothing 4.9 times compared to pure cotton underwear $(p=0.0002)$ (Table 4) This result is similar to a recent study that found that risk factors for VVC include synthetic underwear ${ }^{21,39}$ and another study showed this type of underwear (cotton/synthetic) was 
statistically associated with frequent $\mathrm{VVC}^{40}$ and this may be attributed to the fact that wearing synthetic underwear appears to enhance friction and maceration, thereby increasing local acidity and thus fungal infection. The study discovered that condoms were a protective agent helping to prevent VVC $(\mathrm{OR}=0.2$, $p=0.008$ ) (Table 5). It is unfortunate that this study classified ligation, intrauterine device (IUD), oral contraceptives (OCP), etc. into one category. It was therefore difficult to determine the effect of a particular species on the incidence of VVC (Table 5).

Table 5: Univariate analysis of previous history, reproductive history, and sexual behaviors among women of reproductive age.

\begin{tabular}{|c|c|c|c|c|c|c|}
\hline \multirow[t]{2}{*}{ Character } & \multicolumn{2}{|c|}{$\begin{array}{l}\text { Candida species } \\
\text { positive }(n=21)\end{array}$} & \multirow[t]{2}{*}{ OR } & \multirow[t]{2}{*}{$\mathbf{C I}$} & \multirow[t]{2}{*}{$\mathbf{X}^{2}$} & \multirow[t]{2}{*}{ PV } \\
\hline & No. & $\%$ & & & & \\
\hline \multicolumn{7}{|l|}{ History of vaginitis } \\
\hline Yes $(n=43)$ & 12 & 27.9 & 1.5 & $0.6-3.2$ & 1 & 0.24 \\
\hline No $(n=147)$ & 30 & 20.4 & 0.6 & $0.3-1.44$ & 1 & 0.24 \\
\hline \multicolumn{7}{|c|}{ Frequency of intra-vaginal douching } \\
\hline $\begin{array}{l}\text { Occasionally or never } \\
(\mathrm{n}=79)\end{array}$ & 5 & 6.3 & 0.13 & $0.05-0.3$ & 19 & 00000 \\
\hline Frequently $(\mathrm{n}=111)$ & 37 & 33.3 & 7.1 & 2.6-19 & 19 & 0000 \\
\hline \multicolumn{7}{|c|}{ Frequency of cleaning the vulva } \\
\hline $\begin{array}{l}\text { More than three days } \\
(\mathrm{n}=112)\end{array}$ & 29 & 25.9 & 1.7 & $0.8-3.6$ & 2.2 & 0.13 \\
\hline $\begin{array}{l}\text { Less than two days } \\
(\mathrm{n}=78)\end{array}$ & 13 & 16.7 & 0.57 & $0.2-1.1$ & 2.2 & 0.13 \\
\hline \multicolumn{7}{|l|}{ Contraceptive methods } \\
\hline Condom $(n=41)$ & 3 & 7.3 & 0.2 & $0.06-0.7$ & 7 & 0.008 \\
\hline $\begin{array}{l}\text { Others (ligation, IUD, } \\
\text { and so on) }(n=79)\end{array}$ & 18 & 22.8 & 1.1 & $0.5-2.1$ & 0.03 & 0.89 \\
\hline \multicolumn{7}{|l|}{ Age at marriage } \\
\hline$\leq 20 y(n=97)$ & 27 & 27.8 & 2 & $0.9-4$ & 3.7 & 0.051 \\
\hline$>20 y(n=93)$ & 15 & 16.1 & 0.4 & $0.2-1$ & 3.8 & 0.05 \\
\hline \multicolumn{7}{|c|}{ Frequency of sexual life } \\
\hline $\begin{array}{l}\text { More than twice a } \\
\text { week } n=69 \text { ) }\end{array}$ & 18 & 26.1 & 1.4 & $0.7-2.2$ & 0.99 & 0.31 \\
\hline $\begin{array}{l}\text { Less than once a } \\
\text { week } n=121 \text { ) }\end{array}$ & 24 & 19.8 & 0.7 & $0.3-1.4$ & 0.99 & 0.31 \\
\hline \multicolumn{7}{|c|}{ Cleaning the vulva before or after sexual life } \\
\hline Yes $=133$ & 24 & 18 & 0.4 & $0.2-0.9$ & 4.2 & 0.03 \\
\hline No $(n=57)$ & 18 & 31.6 & 2.1 & $1.0-4.2$ & 4.2 & 0.03 \\
\hline $\begin{array}{l}\text { Diabetic mellitus } \\
(\mathrm{n}=14)\end{array}$ & 4 & 28.6 & 3.7 & $1.1-13.2$ & 4.7 & 0.02 \\
\hline
\end{tabular}

Likewise, Du et al., ${ }^{33}$ Zheng et al., ${ }^{21}$ also found no relationship between OCP and VVC. However, a study reported that there is a link between IUD use and $\mathrm{VVC}^{41}$. Therefore, the role of the IUD in the development of VCC remains unclear, and needs further investigation. At the same time, this study showed that the frequency of vulvar cleaning did not affect the incidence of VVC significantly $(\mathrm{OR}=1.7$, $p=0.13$ ), while vulvar cleaning before or after sexual life was a beneficial factor for VVC prophylaxis $(\mathrm{OR}=0.4, p=0.03)$ (Table 5). There have been a limited number of studies exploring the relationship between the two before ${ }^{21}$. Also pad use while not menstruating may increase the risk of VVC, but in this study, pad use while not menstruating was not a risk factor for VVC (Table 5). Often, sexual life can reduce the risk of suffering from VVC. An observational study reported that sexual contact more often was only associated with asymptomatic colonization ${ }^{42}$. The result did not find a clear association between prior history of vaginitis and suffering from VVC $(\mathrm{OR}=1.5$, $p=0.24$ ) (Table 5). This finding was different from some previous epidemiological studies that believed that there was an association between episodes of VVC symptoms and a history of lower genital tract infection $^{32,43,44}$. Besides, the study was concerned with the effect of daily emotional state, in the end, positive emotions were a protective factor $(\mathrm{OR}=0.47, p=0.001)$, while negative feelings (nervousness, anxiety, etc.) were risk factors $(\mathrm{OR}=2.3, p=0.001)$ (Table 4) and increased susceptibility to VVC approximately 2.3fold. So far, little is known about the relationship between affective factors and VVC prevalence.

\section{CONCLUSION}

The study has demonstrated a high incidence of VVC among non-pregnant women and this highlights the need for health authorities to develop strategies for diagnosing VVC, including vaginal swabs for 
candidiasis as a standard method for all women who attend family centers. This study also revealed a steady increase in time with non- $C$. albicans species spreading. Guidelines for the management of VVC syndrome in Yemen should be revised to include a protocol specifically for women over 30 years of age. VVC clearly poses a significant threat to women's reproductive health. Risk factors for VVC are varied, and include ages, health habits, history of the disease, and other aspects. It is necessary to take appropriate measures to avoid risk factors and to help reduce the prevalence of VVC among women of childbearing age.

\section{ACKNOWLEDGEMENTS}

The authors would like to thank the Ministry of Health and Population, Sana'a, Yemen and the National Center for Public Health Laboratories (NCPHL), the Ministry of Health and Population, Sana'a, Yemen for their support and the provision of workplaces and materials.

\section{AUTHOR'S CONTRIBUTION}

This research work is part of a National Center for Public Health Laboratory (NCPHL) project. The authors did clinical and laboratory work. The first author (SMMA) was the lead author on the project, and the corresponding author (HAA) supervised the work of the laboratory, reviewing and editing the research.

\section{CONFLICT OF INTEREST}

There is no conflict of interest with this research.

\section{REFERENCES}

1. Alhasani AH, Al-Akwa AA, Al-Shamahy HA, Al-deen HMS, Al-labani MA. Biofilm formation and antifungal susceptibility of candida isolates from oral cavity after the introduction of fixed orthodontic appliances. Universal $\mathrm{J}$ Pharm Res 2020; 5(4):1-6.

https://doi.org/10.22270/ujpr.v5i4.435

2. Al-deen HMS, Obeyah AA, Al-Shamahy HA, Al-Shami IZ, AL-amri MAS, Al-labani MA. Oral Candida albicans colonization rate in fixed orthodontics patients. Universal $\mathbf{J}$ Pharm Res 2020; 5( 2):1-6. https://doi.org/10.22270/ujpr.v5i2.380

3. Al-Kebsi AA, Othman A, Abbas KM, Madar E, AlShamahy HA, Al-Gaffari KM, Daname MD, Motareb F. Oral $C$. albicans colonization and non-candida albicans candida colonization among university students, Yemen. Universal J Pharm Res 2017; 2(5):1-8. https://doi.org/10.22270/ujpr.v2i5.R2

4. Edrees WH, Al-Asbahi AA, Al-Shehari WA, Qasem EA. Vulvovaginal candidiasis prevalence among pregnant women in different hospitals in Ibb, Yemen. Universal $\mathbf{J}$ Pharm Res 2020; 5(4): 1-6.

https://doi.org/10.22270/ujpr.v5i4.431

5. Al-Rukeimi AA, Al-Hatami SMM, AL-Danany DA, AlShamahy HA, Al Rukeimi RAA. Prevalence and risk factors associated with vulvovaginal candidiasis during pregnancy in Sana'a, Yemen. Universal J Pharm Res 2020; 5(3):1-6. https://doi.org/10.22270/ujpr.v5i3.407

6. Al-Haddad KA, Al-dossary OAE, Al-Shamahy HA. Prevalence and associated factors of oral non-candida albicans candida carriage in denture wearers in Sana'a cityYemen. Universal J Pharm Res 2018; 3(4):1-6. https://doi.org/10.22270/ujpr.v3i4.176
7. Al-Sanabani N, Al-Kebsi A, Al-Shamahy HA, Abbas KM. Etiology and risk factors of stomatitis among Yemeni denture wearers. Universal J Pharm Res 2018; 3(1):1-6. https://doi.org/10.22270/ujpr.v3i1.R9

8. Goncalves B, Ferreira C, Alves CT, et al. Vulvovaginal candidiasis: epidemiology, microbiology and risk factors. Crit Rev Microbiol 2016; 42:905-27. http://dx.doi.org/10.3109/1040841x.2015.1091805

9. Sobel JD. Vulvovaginal candidosis. The Lancet 2007; 369 (9577):1961-1971 https://doi.org/10.1016/S0140-6736(07)60917-9

10. Peters BM, Yano J, Noverr MC, Fidel Jr PL. Candida vaginitis: when opportunism knocks, the host responds. PLoS Pathogens 2014; 10(4):1-5. Article IDe1003965, 2014. https://doi.org/10.1371/journal.ppat.1003965

11. Ehan A. Alsharifi. Epidemiology of vaginal candidiasis among pregnant women attending Tikrit teaching hospital/Iraq. J Fac Med Baghdad 2017; 59(4):1-5. https://doi.org/10.32007/med.1936/ifacmedbagdad.v59i4.10

12. Altayyar IA, Alsanosi AS, Osman NA. Prevalence of vaginal candidiasis among pregnant women attending different gynecological clinic at South Libya. European J Exp Biol 2016;6(3):25-29.

13. Al-akeel RA, El-Kersh TA, Al-Sheik YA, AlAhmady ZZ. Prevalence and comparison for detection methods of Candida species in vaginal specimens from pregnant and non pregnant Saudi women. African J Microbiol Res 2013; 7(1):56-65. http://www.academicjournals.org/AJMR

14. AbdulAziz M, Mahdy MAK, AbdulGhani R, et al. Bacterial vaginosis, vulvovaginal candidiasis and trichomonal vaginitis among reproductive-aged women seeking primary healthcare in Sana'a city, Yemen. BMC Infect Dis. 2019; 19(1):879. https://doi.org/10.1186/s12879-019-4549-3

15. Al-Haik WM. Al-Haddad AM. Bacterial vaginosis among pregnant women in Hadhramout-Yemen. AUST J 2017; 16(7):23-33.

16. Edrees W, Alshwmi M, Al-Ofairi B. Prevalence and antifungal susceptibility of Candida species causing vaginitis among pregnant women in Hajjah Governorate, Yemen. Al-Razi Univ J Med Sci 2021; 5(1): 1-11. https://rujms.alraziuni.edu.ye/index.php/rzjournal/article/vie w/85

17. Hamad M, Kazandji N, Awadallah S, Allam H. Prevalence and epidemiological characteristics of vaginal candidiasis in the UAE. Mycoses 2014; 57(3):184-190. https://doi.org/10.1111/myc.12141

18. Allsworth JE, Peipert JF. Prevalence of bacterial vaginosis: 2001-2004 national health and nutrition examination survey data. Obstet Gynecol 2007; 109(1):114-120. https://doi.org/10.1097/01.AOG.0000247627.84791.91

19. Borman AM, Szekely A, Linton CJ, Palmer MD, Brown P, Johnson EM. Epidemiology, antifungal susceptibility, and pathogenicity of Candida africana isolates from the United Kingdom. J Clin Microbiol 2013; 51(3):967-972. https://doi.org/10.1128/JCM.02816-12

20. Ilkit M, Guzel AB. The epidemiology, pathogenesis, and diagnosis of vulvovaginal candidosis: A mycological perspective. Crit Rev Microbiol 2011; 37(3): 250-261.

21. Xianling Z, Zhang Y, Zhang T, et al. Risk Factors of Vulvovaginal candidiasis among women of reproductive age in Xi'an: a cross-sectional study. Hindawi Bio Med Research International 2018. https://doi.org/10.1155/2018/9703754

22. Anderson MR, Klink K, Cohrssen A. Evaluation of vaginal complaints. JAMA. 2004 Mar 17; 291(11):1368-79. https://doi.org/10.1001/jama.291.11.1368

23. Ahmad A, Khan AU. Prevalence of Candida species and potential risk factors for vulvovaginal candidiasis in Aligarh, India. Eur J Obstet Gynecol Reprod Biol 2009; 144(1):68-71. https://doi.org/10.1016/j.ejogrb.2008.12.020

24. Olowe OA, Makanjuola OB, Olowe R, Adekanle DA. Prevalence of vulvovaginal candidiasis, trichomoniasis and bacterial vaginosis among pregnant women receiving 
antenatal care in Southwestern Nigeria. Eur J Microbiol Immunol 2014; 4:193-7.

https://doi.org/10.1556/EUJMI-D-14-00027

25. Rylander E, Berglund AL, Krassny C, Petrini B. Vulvovaginal candida in a young sexually active population: prevalence and association with oro-genital sex and frequent pain at intercourse. Sex Transm Infect 2004; 80(1):54-7. https://doi.org/10.1136/sti.2003.004192

26. Sobel JD. Candidal vulvovaginitis. Clin Obstet Gynecol. 1993 Mar; 36(1):153-65. https://doi.org/10.1097/00003081-199303000-00021

27. Xu J, Schwartz K, Bartoces M, Joseph M, Severson R, Sobel JD. Effect of antibiotics on vulvovaginal candidiasis: a Metro Net study. J Am Board Fam Med 2008; 21:261-8. https://doi.org/10.3122/jabfm.2008.04.070169

28. Spinillo A, Capuzzo E, Nicola S, et al. The impact of oral contraception on vulvovaginal candidiasis. Contraception 1995; 51: 293-7. https://doi.org/10.1016/0010-7824(95)00079-p

29. Paulitsch A, Weger W, Ginter-Hanselmayer G, Marth E, Buzina W. A 5-year (2000-2004) epidemiological survey of Candida and non-Candida yeast species causing vulvovaginal candidiasis in Graz, Austria. Mycoses 2006; 49:471-5.https://doi.org/10.1111/j.1439-0507.2006.01284.x

30. Holland J, Young ML, Lee O, Chen SCA. Vulvovaginal carriage of yeasts other than Candida albicans. Sex Trans Inf 2003; 79(3): 249-250.

http://dx.doi.org/10.1136/sti.79.3.249

31. Vaca M, Guadalupe I, Erazo S, et al. High prevalence of bacterial vaginosis in adolescent girls in a tropical area of Ecuador. BJOG: An Int J Obst Gynaecol 2010; 117(2): 225-228. https://doi.org/10.1111/j.1471-0528.2009.02397.x

32. Amouri I, Sellami H, Borji N, et al. Epidemiological survey of vulvovaginal candidosis in Sfax, Tunisia. Mycoses 2011 Sep; 54(5):e499-505 https://doi.org/10.1111/j.1439-0507.2010.01965.x

33. Du Na D, Weiping L, Enfeng Z, Chan W, Zhaozhao X, Honghui Z. Risk factors for Candida infection of the genital tract in the tropics. African Health Sci 2014;14( 4): 835839. http://dx.doi.org/10.4314/ahs.v14i4.10

34. Curran J, Hayward J, Sellers E, Dean H. Severe vulvovaginitis as a presenting problem of type 2 diabetes in adolescent girls: A case series. Pediatrics 2011;127(4):e1081-e1085, 2011. http://dx.doi.org/10.1542/peds.2010-2311

35. Gunaid AA, Assabri AM. Prevalence of type 2 diabetes and other cardiovascular risk factors in a semirural area in Yemen. Eastern Mediterranean Health J 2008; 14(1):1-8. PMID: 18557451
36. Nyirjesy P, Zhao Y, Ways K, Usiskin K. Evaluation of vulvovaginal symptoms and Candida colonization in women with type 2 diabetes mellitus treated with canagliflozin, a sodium glucose co-transporter 2 inhibitor. Curr Med Res Opin 2012; 28(7):1173-8. https://doi.org/10.1185/03007995.2012.697053

37. Lattif AA. Molecular typing and in vitro fluconazole susceptibility of Candida species isolated fromdiabetic and nondiabetic women with vulvovaginal candidiasis in India. J Microbiol Immunol Infect 2011; 44(3):166-171 https://doi.org/10.1016/j.jmii.2011.01.020

38. Brown JM, Hess KL, Brown S, Murphy C, Waldman AL, Hezareh M. Intravaginal practices and risk of bacterial vaginosis and candidiasis infection among a cohort of women in the United States. Obstet Gynecol 2013; 121( 4):773-780.https://doi.org/10.1097/AOG.0b013e31828786f8

39. Ogouy`emi-Hounto A, Adisso S, Djamal J, et al. Place of vulvovaginal candidiasis in the lower genital tract infections and associated risk factors among women in Benin. $\mathbf{J}$ de Mycologie M'edicale 2014; 24(2):100-105 https://doi.org/10.1016/j.mycmed.2014.01.003

40. Antuono AD, Baldi E, Bellavista S, Banzola N, Zauli S, Patrizi A. Use of Dermasilk briefs in recurrent vulvovaginal candidosis: Safety and effectiveness. Mycoses 2012 55(3):e85-e89.

http://dx.doi.org/10.1111/j.1439-0507.2011.02102.x

41. Chassot F, Negri MFN, Svidzinski AE, et al. Can intrauterine contraceptive devices be a Candida albicans reservoir? Contracep 2008; 77(5):355-359. https://doi.org/10.1155/2018/9703754

42. Watson CJ, Fairley CK, Grando D, Garland SM, Myers SB, Pirotta M. Associations with asymptomatic colonization with candida in women reporting past vaginal candidiasis: an observational study. European J Obst Gynecol Reprod Biol 2013; 169( 2):376-379. http://dx.doi.org/10.1016/j.ejogrb.2013.03.030

43. Giraldo P, VonNowaskonski A, Gomes FAM, Linhares I, Neves NA, Witkin SS. Vaginal colonization by Candida in asymptomatic women with and without a history of recurrent vulvovaginal candidiasis. Obst Gynecol 2000; 95(3):413-416 http://dx.doi.org/10.1016/s0029-7844(99)00577-3

44. Patel DA, Gillespie B, Sobel JD, et al. Risk factors for recurrent vulvovaginal candidiasis in women receiving maintenance antifungal therapy: Results of a prospective cohort study. American J Obst Gynecol 2004; 190 (3):644653.http://dx.doi.org/10.1016/j.ajog.2003.11.027 